Niniejsza publikacja jest dostęna na licencji Creative Commons. Uznanie autorstwa-Użycie niekomercyjne-Bez utworów zależnych 3.0 Polska. Pewne prawa zastrzė̇one na rzecz autora. Zezwala się na wykorzystanie publikacji zgodnie z licencja - pod warunkiem zachowania niniejszej informacji licencyjnej oraz wskazania autora jako właściciela praw do tekstu. Treść licencji jest dostępna na stronie: http://creativecommons.org/licenses/by-nc-nd/3.0/pl/

Lingwistyka Stosowana 19: 4/2016, 229-242

\author{
Jerzy ŻMUDZKI
}

Uniwersytet Marii Curie-Skłodowskiej w Lublinie

\title{
Ekwiwalencja translacyjna - próba określenia jej aktualnego statusu jako zjawiska i terminu w ogólnej perspektywie translatorycznej
}

\begin{abstract}
:
Dealing with Equivalence in Translation - an Approach to explain its actual Status as real Phenomenon in Translation Process and as a Term within a hole Perspective of Translation Theory

The article outlines and evaluates various concepts of equivalence in Translation Studies with special regard to its ontological and processual relativism. Finally the paper elaborates on the anthropological base of explanation the new concept and determination of functional criterions, which make possible, to overcome the fundamental opposition between fidelity and freedom in translation and to establish the functional solution of a special sort of theoretical proem in the theory of translation.
\end{abstract}

Zagadnienie ekwiwalencji translacyjnej, którym chciałbym się zająć w niniejszym tekście zgodnie z jego zaanonsowaniem tematycznym w tytule, należy bez wątpienia do klasycznych kwestii/zagadnień poruszanych w dyskursie translatorycznym, translatologicznym, przekładoznawczym czy też w ramach tzw. lingwistyki translacji a także lingwistyki kognitywnej, lingwistyki tekstu, który był prowadzony wzgl. uprawiany na przestrzeni wielu wieków w ramach różnych dyscyplin, tradycji, szkół, paradygmatów a także profili badawczych i jest kontynuowany aż po dzień dzisiejszy. Ze względu na ograniczenia wynikające ze specyfiki tej publikacji nie możliwe jest przeprowadzenie w tym wymiarze i zakresie, być może oczekiwanego, pełnego bilansu historycznego kształtowania się i rozwoju pojęcia i terminu ekwiwalencji. Skoncentruję się natomiast na głównej charakterystyce dynamiki koncepcyjnej ekwiwalencji translacyjnej i zaprezentowaniu nowych jej interpretacji.

Zadeklarowana próba ponownego przedyskutowania tego zagadnienia, być może ryzykowna $\mathrm{z}$ uwagi na aporyczny charakter wielu dotychczas prezentowanych rozwiązań i definicyjnych określeń tego rodzaju specyficznej relacji między tekstem wyjściowych a jego translatem znajduje swą bezpośrednią motywację w istniejącej różnorodności interpretacji i koncepcji zjawiska oraz obszaru pojęciowego tego terminu. Zatem przegląd referujący i charakteryzujący koncepcje ekwiwalencji oraz terminy pokrewne jej pojęciowo będzie musiał zawierać niezbędną selekcję repre- 
zentatywną i typologicznie uogólnioną, wykazującą przede wszystkim krajobraz różnic terminologicznych i definicyjnych. Efektem tych ewaluacji powinna być końcowa propozycja określenia zespołu kryteriów jako odniesień determinujących relacje równoważności między tekstem wyjściowym a docelowym i wykazania dzięki temu zabiegowi obszaru czynników determinujących i w odpowiedni sposób kształtujących tę relację. Wspomniane kryteria postaram się wywieść z paradygmatu antropocentrycznego zastosowanego do analizy i interpretacji rzeczywistości translacyjnej w ramach jej ontologicznych uwarunkowań.

Podstawę definicyjną terminu (wyrażenia) „ekwiwalencja”, zapożyczonego w teoriach translacji z matematyki i logiki, stanowi tożsamość/podobieństwo a także różnica charakteryzujące relację pomiędzy tekstem wyjściowym a docelowym. (Pojęcie różnicy zgodnie z teorią Heideggera (2010) jest bowiem implikowane istnieniem tożsamości a nie identyczności.) Jednakże owa tożsamość począwszy od koncepcji Arystotelesa, która miała stanowić podstawę pojęcia ekwiwalencji a zwłaszcza obszar jej operowania, ulegała w różnych koncepcjach translacji i jej modelach teoretycznych zmianom $\mathrm{i}$ istotnym przesunięciom definicyjnym. Wynikały one $\mathrm{z}$ różnego wzgl. odmiennego profilowania interpretacyjnego omawianej/badanej podstawowej relacji między tekstem wyjściowym a translatem poza lub $\mathrm{w}$ ramach procesu translacji w zależności od stosowanego paradygmatu metodologicznointerpretacyjnego. Wspomnianą dynamikę kształtowania się tego terminu oraz rozwoju jego zakresu pojęciowego $\mathrm{w}$ ramach refleksji translatorycznej bardzo trafnie ujmuje i syntetyzująco prezentuje D. Urbanek (2004: 90-124). Wyróżnia ona 3 etapy ewolucji poglądów na relację przekładu do oryginału omawiając dokładnie i szeroko koncepcje ekwiwalencji na tle kształtowania się różnych teorii translacji. Etapy te tworzą i charakteryzują następujące właściwości tej relacji i procesu:

1. tożsamość i podobieństwo;

2. podobieństwo $\mathrm{z}$ rozszerzonym zakresem o aspekt komunikacyjnopragmatyczny, wartość komunikacyjną, o perspektywę procesu translacji wychodzącą poza tę podstawową relację, gdzie tenże proces rozpatrywany jest jako zjawisko mimesis;

3. różnicowanie naturalne $\mathrm{w}$ procesie translacji i wynikające stąd różnicujące nacechowanie translatu względem oryginału.

W zakresie wymienionych trzech etapów wspomniana dynamika kształtowania się poglądów na tę podstawową relację dotyczy nie tylko zmiany zakresu pojęciowego tego terminu, lecz ukazuje przede wszystkim istotny kierunek owych zmian, a mianowicie stopniowe odchodzenie od tożsamościowego pojmowania/ interpretowania tej relacji. Bowiem poglądy na translację, zwłaszcza na etapie początkowym zawierały przede wszystkim dość restrykcyjne traktowanie związku pomiędzy oryginałem a translatem tzn. w kategoriach równoważności tożsamościowej, charakteryzującej również sam proces translacji oraz postulowanej $\mathrm{w}$ ramach określonych oczekiwań czy też preskrypcji zadaniowych i jakościowych. $\mathrm{Z}$ tego też względu takie tożsamościowe pojmowanie dyskutowanej relacji spowodowało zapożyczenie nazwy „ekwiwalencja” z logiki i matematyki poprzez analogię cech definiowanych przez te dyscypliny a zjawiskiem translacyjnym, w wyniku czego skutki stały dość 
widoczne w fazie formalno-lingwistycznego traktowania tej relacji. W ujęciu ogólnym trójetapowej charakterystyki tworzony był określony metajęzyk opisu zarówno w kategoriach statycznych, odnoszących się do wyniku translacji, a także dynamicznych, charakteryzujących sam proces translacji. Efektem refleksji translatorycznej, dotyczącej zjawiska ekwiwalencji translacyjnej w powyższym usystematyzowaniu, było wyłonianie i określanie coraz to innych typów wzgl. rodzajów ekwiwalencji z jednej strony; z drugiej zaś strony miało miejsce wprowadzanie innych terminów konkurujących z ekwiwalencją jako terminem oraz z jej definicją lub w najlepszym razie synonimicznych do niej po to, aby precyzyjniej oznaczyć nowe aspekty wyróżnione w ramach interpretacji rzeczywistości translacyjnej.

W zależności od sposobu postrzegania i interpretowania tej relacji używano różnych nazw o charakterze terminologicznym, które miały na celu utrwalenie efektów tejże interpretacji oraz zachowanie jak najwyższego stopnia adekwatności konceptualizacyjnej charakteryzującej daną teorię. Wspomniana różnorodność nazw dla oznaczenia tej relacji dość ilustratywnie charakteryzuje krajobraz koncepcyjny i terminologiczny wyłaniający się z badań i refleksji nad tym fundamentalnym zjawiskiem translacyjnym. Do najbardziej znanych terminów konkurencyjnych, synonimicznych lub też zastępczych względem ekwiwalencji, używanych w różnych koncepcjach zarówno translacji jak też i ekwiwalencji i występujących w translatoryce, przekładoznawstwie czy też translatologii należy zaliczyć:

1. odpowiedniość - B.Z. Kielar (1988: 60);

2. inwariancję" - O. Kade (1968: 11), R.K. Minjar-Bełoruczew (1980: 37), A. D. Szwejcer (1988: 85);

3. relewancję - E. A. Gutt $(1991,1997)$;

4. adekwatność - K. Reiss/H.-J. Vermeer (1984: 139);

1. 5. intertekstualność - D. Urbanek (2004: 133-145), A. Pym (1992),

D. Kenny (1998: 80), B. $\quad$ Z. Kielar (2003: 47), R. Nycz (1993);

5. koherencję translacyjną - P. Kussmaul (1986: 224);

6. optymalność (jako analogon pojęcia adekwatności) - J. Ziomek (1975: 47);

7. wierność - R. Ingarden (2000: 97-118), W. Koller (1992: 227);

8. lojalność - L. Venuti (1995), W. Koller (1992: 227), Chr. Nord (1989: 102);

9. prototyp semantyczny - M. Snell-Hornby (1988: 26-31, 263), D. Cruse (1992: 20-30);

10. zbieżność obrazowania - E. Tabakowska (2001: 100);

11. aproksymację - J.-R. Ladmiral (1981: 393), J. Żmudzki (1991);

12. analogię i podobieństwo - B. Lewandowska-Tomaszczyk (2010: 23-27);

13. implikację - H. Siever (2010: 309).

Ewolucję poglądów na ekwiwalencję jako fundamentalną relację pomiędzy tekstem wyjściowym a docelowym i tym samym na istotę procesu translacji charakteryzuje przede wszystkim odniesienie do dwóch fundamentalnych kategorii, determinujących zarówno proces translacji jak też i jego produkt, a mianowicie ,wierność" i „Wolność” (lub też niewierność) względem oryginału, z których dyskutowana relacja wywodzi się stanowiąc jej genezę. Ich naturalne występowanie w ramach każdego procesu translacji wymuszało pytanie dotyczące rozstrzygnięcia tej wzajemnej 
sprzeczności występującej przede wszystkim w ramach praktyki translacji, w której zawsze zachodzi tworzenie określonego kompromisu. Pytanie to i odpowiedź w postaci tzw. maksymy translacyjnej, uznawanej za klasyczną, miał sformułować już św. Hieronim (1973) w znanym dziele „Vulgata”. Zgodnie z tą maksymą tłumaczyć należy tak wiernie, jak to jest możliwe i tak swobodnie tzn. niewiernie, jak to jest konieczne. Jednakże odpowiedź ta z pozoru nie zawierała rozwiązania tej sprzeczności pomimo uprawianej przez tysiąclecia praktyki translacji i powodowała w kształtowaniu się refleksji translatorycznej czy też translatologicznej przyznanie tej bipolarnej konstelacji statusu aporemu. Przyczynę takiego stanu rzeczy wyjaśnia dość dokładnie R. Stolze (2003: 145) wykazując, że traktowanie tej relacji w kategoriach alternatywy powoduje trwanie $\mathrm{w}$ obrębie aporii jako stanu nierozwiązywalności tego problemu. Tworząc konstelację alternatywną oba te pojęcia zawierają $\mathrm{w}$ obszarach swych odniesień cały szereg pomniejszych pytań szczegółowych np.:

a) jak należy definiować „wierność”?

b) do jakich konstytuentów tekstu wyjściowego kategoria wierności odnosi się?

c) które $\mathrm{z}$ tych konstytuentów thumacz powinien $\mathrm{w}$ sensie dezyderatywnym „Zachować” $\mathrm{w}$ tekście docelowym?

d) czy relacja wierności względem tekstu wyjściowego jest stopniowalna?

e) które konstytuenty tekstu wyjściowego w procesie translacji będą objęte ze względu na jego specyfikę ontologiczną kategorią wierności względnej (relatywnej) a które wolnością od wierności czyli zmiennością w zakresie inwariancji?

Próby rozstrzygnięcia pomiędzy wiernością a wolnością w translacji, co zawsze prowadzi do stworzenia konkretnej relacji ekwiwalencji między tekstem wyjściowym a jego translatem przede wszystkim w każdym procesie translacji, znajdujemy w klasycznych teoriach św. Hieronima, Lutra czy też Schleiermachera, którzy w ramach swych rozwiązań formułowali konkretne zalecenia dezyderatywne. I tak św. Hieronim (1973 passim) opowiadał się za zachowaniem ciągłości sensów w translacie wyłączając formę językową tekstu wyjściowego poza zakres wierności i włączając ją jednocześnie do obszaru wolności translacyjnej. Luter (1973 passim) natomiast podkreślał $\mathrm{z}$ jednej strony wagę interpretacji indywidualnej oryginału przez thumacza z drugiej zaś świadome wyprofilowanie tekstu docelowego w dostosowaniu go do potrzeb adresata. A zatem wolność pojmował w zorientowaniu na adresata i taką orientację traktował jako zadanie pragmatyczne i legitymizację tejże wolności. Schleiermacher (1838: 47) rozpatruje tę alternatywę translatoryczną w taki sposób, że po pierwsze wykazuje dwukierunkowość procesu translacji w sensie jej albo retrospektywności albo prospektywności, opowiada się przeciwko dopasowaniu autora oryginału do adresata translacji oraz przeciwko mieszaniu tych dwu kategorii wierności i wolności a przede wszystkim wykazuje dominację orientacji na tekst wyjściowy/jego autora nawet kosztem występowania elementów obcości w translacie. Podkreśla przy tym fakt indywidualnej interpretacji tekstu wyjściowego w każdym procesie translacji przez tłumacza.

Jeden z klasyków współczesnej teorii translacji O. Kade (1968) zdecydowanie przeciwstawia się traktowaniu relacji między tymi kategoriami jako rzeczywistej 
alternatywy. Bowiem w każdym procesie translacji podejmowane są konkretne decyzje dotyczące określenia granic tego, co stanowi możliwość wiernej wzgl. dosłownej translacji, gdyż dopiero to skutkuje wyłonieniem konieczności translacji niewiernej tzn. wolnej od determinacji przez tekst wyjściowy. Kade uważa zatem, iż możliwość wierności w przypadku konkretnej translacji implikuje konieczność wolności translacyjnej. Jako rozwiązanie proponuje pewien rodzaj syntezy pomiędzy tymi sprzecznościami, którą opiera na zasadzie dialektycznej. W myśl tej zasady treść i forma tekstu tworzą dialektyczną całość tekstu, wzajemnie się warunkując, pomimo tego, że pozostają w pewnej sprzeczności względem siebie. Jednakże jako obszar dominujący tekstu, zachowujący prymat w podejmowaniu decyzji translacyjnych uznaje on jednoznacznie płaszczyznę treści jako obszar odniesienia, przypisuje mu w związku z tym status stałości/niezmienności (inwariancji) i traktuje jednocześnie jako bazę zobowiązania tłumacza do wierności a tym samym ekwiwalencji. Zastępuje w taki sposób pojęcie wierności pojęciem ekwiwalencji a pojęcie wolności pojęciem ,nieekwiwalencji” wzgl. jej brakiem. Z takiej interpretacji wyłania się dominacja tekstu wyjściowego jako główna orientacja w translacji o charakterze retrospektywnym. Innym klasycznym przedstawicielem takiej orientacji jest także W. Koller (2004: 226).

Ponieważ i te rozwiązania o alternatywnym wyprofilowaniu cechowała w dalszym ciągu trudna do przezwyciężenia aporyczność i jednostronność rozwiązania translatorycznego, pojawiły się próby poszerzenia perspektywy translacyjnej o określone parametry i współczynniki procesu translacji, które były sukcesywnie włączane do modelowania interpretacyjnego tego obszaru rzeczywistości translacyjnej i wyłaniania zakresu tworzącego fundament relacji ekwiwalencji. Określony przełom w tym zakresie spowodowały poglądy i prace takich badaczy i teoretyków w Niemczech jak K. Reiss i H.-J. Vermeer (1984), J. Holz-Mänttäri (1984 i 1986), W. Wilss (1988), M. Snell-Hornby (1988), Chr. Nord (1989 i 1999), R. Stolze (2003: 144). Wspólną cechą charakteryzującą koncepcje translacji oraz ekwiwalencji translacyjnej wymienionej grupy badaczy było zorientowanie procesu translacji na cel czyli skopos oraz jego odniesienie do innych parametrów i współczynników warunkujących to teleologiczno-funkcjonalne wyprofilowanie całego kompleksu operacji translacyjnych. Taka orientacja sygnalizowała jednoznacznie dominację prospektywności w pojmowaniu translacji i otwierała jednocześnie perspektywę i zasadę funkcjonalnie koniecznej wolności od tekstu wyjściowego zgodnie ze znaną maksymą funkcjonalistów, że cel uświęca środki. Jednakże z drugiej strony ten radykalizm funkcjonalny rodził określone zagrożenie uwikłania się w subiektywizm funkcjonalny w postaci absolutnej wzgl. nieograniczonej wolności tłumacza. Tego rodzaju zagrożenia trafnie identyfikuje R. Stolze (2003: 144) poddając je zdecydowanej krytyce. Interpretacyjne poszerzenie modelu translacji, zaproponowane przez K. Reiss i H.-J. Vermeera, podejmuje w swych pracach Chr. Nord (1991: 102) wyprowadzając kategorię wolności, w jej rozumieniu jako lojalność, zdecydowanie poza tekst wyjściowy i uzależniając ją od takich współczynników procesu translacji i jednocześnie jego parametrów jak: zleceniodawcy, odbiorcy tekstu docelowego, autora tekstu wyjściowego, funkcjonujących jako partnerzy wzgl. aktanci działania 
translacyjnego. W takim modelu kategoria wolności translacyjnej uzyskuje rangę wolności funkcjonalnej, która jest realizowana kosztem tekstu wyjściowego. W podobnym kierunku argumentują H. Hönig/P. Kussmaul (1982: 19) und P. Kussmaul (2000:32) oraz W. Wilss (1988) opowiadając się za dominacją podejścia prospektywnego. Uważają oni mianowicie, że w każdym procesie translacji nie zachodzi jedynie zwykłe odtwarzanie, ,rekreowanie" tekstu wyjściowego, lecz kreatywne różnicowanie tekstu wyjściowego $\mathrm{w}$ tekście docelowym. W związku z tym w procesie translacji zachodzi naturalna konieczność dyferencjacji tekstu wyjściowego przez tłumacza. I w tym punkcie R. Stolze (2003:149) rozpoznaje określone zagrożenia dotyczące braku ustalenia parametrów i odniesień wyznaczających granice tej kreatywnej wolności wzgl. swobodnej kreatywności tłumacza i jego zasadnego uwalniania się od tekstu wyjściowego. Swego rodzaju dynamizację interpretacyjną i przezwyciężenie aporyczności tej relacji proponuje J. Holz-Mänttäri (1984 passim) w jej teorii działania translacyjnego włączając do modelu procesu translacji tłumacza wraz z jego zadaniem translacyjnym legitymizującym konieczną dyferencjację tekstu docelowego względem wyjściowego.

W dyskusji rozpatrującej stosunek tych dwu kategorii do siebie tworzących relacje ekwiwalencji warto jednakże zwrócić uwagę na czynniki determinujące te zasadnicze modalności usytuowane przede wszystkim w procesie translacji, ponieważ to one właśnie oddziaływają regulująco na proces translacji i wpływają na konkretne rozstrzygnięcia tłumacza funkcjonującego w układzie tych dwu pozornie przeciwstawnych kategorii, ponieważ $\mathrm{w}$ procesie translacji zawsze uzewnętrznia się ich charakter komplementarny. I w tym kierunku idą interpretacje i modelowanie relacji ekwiwalencji, prowadzone i kontynuowane są także próby formułowania określonych rozwiązań również na gruncie polskiej translatoryki. Dotyczą one w takiej samej mierze rozpatrywania wzajemnej relacji pomiędzy kategorią wierności i wolności w translacji wraz z ich specyfiką modalnościową. Przykład reprezentatywny w tym zakresie stanowi koncepcja D. Urbanek (2004), która w swym modelu translacji wyróżnia bardzo charakterystyczną cechę tej relacji a mianowicie paradoks ontologiczny. Opierając się na poglądach E. Kasperskiego (1992: 70-71) za punkt wyjścia obiera klasyczna zasadę mimesis charakteryzującą zarówno proces jak też i jego rezultat. Oba te obszary są determinowane przez dwa rodzaje modalności: po pierwsze przez konieczność związku pomiędzy oryginałem a translatem tzn. pomiędzy obiektem naśladowanym i naśladującym. Jednakże ten ostatni musi zawierać konieczne podobieństwo do oryginału czyli zachować wierność względem niego ale nie identyczność. Drugi rodzaj modalności to konieczność różnicy (wolności) obiektu naśladującego wobec naśladowanego. $Z$ tego też względu Urbanek odróżnia ontologię referencji tekstu docelowego względem wyjściowego od ontologii utworu naśladującego $\mathrm{w}$ zakresie jego kreatywnej autonomii funkcjonalnej. Ze względu na wzajemne warunkowanie się tych dwu ontologii w ramach translacji Urbanek znajduje następujące rozwiązanie: dla współistnienia tych sprzeczności proponuje termin ontologia komplementarności. A zatem konieczność podobieństwa jako ontologia referencji wzgl. wierności implikuje konieczność różnicy i różnicowania $\mathrm{w}$ ramach ontologii komplementarności wzgl. wolności. U podstaw tak pojmowanej mime- 
tyczności leży według Urbanek paradoks ontologiczny. Ukazuje on bardzo wyraźnie status translatu z jednej strony jako tworu wtórnego (sekundarnego) względem oryginału z drugiej zaś jako komplementarnie autonomicznego. Zarówno wspomniana sekundarność jak też komplementarna autonomia mogą być w zależności od konkretnego przypadku translacji w różnym stopniu poszerzane lub zawężane. Jednakże i w tej teorii ontologia referencji oraz ontologia komplementarności jako koniecznego różnicowania pozbawione są istotnych kryteriów determinacji modalnościowych pomimo uznania koncepcji komplementarności translacji przez D. Urbanek za tzw. „złoty środek”.

Kolejną interesującą próbę nowej interpretacji zjawiska ekwiwalencji translacyjnej podejmuje również B. Lewandowska-Tomaszczyk (2010: 23). Wychodzi ona najpierw od krytyki pojmowania ekwiwalencji na sposób arystotelesowski czyli jako relacji ,jednoznaczności pomiędzy dwoma takimi samymi systemami” uważając, że w takim jej rozumieniu ekwiwalencja w przekładzie nie istnieje ze względu na istniejące różnice systemowe. Twierdzi natomiast, iż istnienie pewnych analogii, pewnych typów podobieństwa między systemami uzasadnia wystarczająco pojmowanie ekwiwalencji translacyjnej jako analogii i podobieństwa, które są warunkiem koniecznym i nieodzownym każdej translacji. Wskazuje na stopniowalność ekwiwalencji między tekstem wyjściowym a docelowym, która wynika ze zróżnicowania w skutek rekonceptualizacji i rekontekstualizacji, charakteryzujących proces translacji i wpływających na decyzje tłumacza odnośnie zapewnienia określonego stopnia ekwiwalencji. Bardzo cennym zabiegiem jest określenie kryteriów konstruowania podobieństwa w oparciu o takie parametry, jak typ komunikacji i wykorzystywane przez niego rodzaje podobieństwa i skale. W ramach typów komunikacji B. Lewandowska-Tomaszczyk wyróżnia komunikację aproksymacyjną, równoległą i uszczegółowioną, która reguluje rodzajami podobieństwa, jak:

A. podobieństwo fizyczne: fonetyczne, graficzne/grafemiczne;

B. podobieństwo konceptualne: naturalne - prototyp kulturowy, składnikowe definicja, funkcjonalne, symboliczne, perspektywizujące, aksjologiczne, ideologiczne, polisemiczne, metonimiczne, metaforyczne;

C. podobieństwo statystyczne (frekwencja): jednowymiarowe, wielowymiarowe;

D. podobieństwa złożone jako zgrupowanie wyżej wymienionych kryteriów o różnym rozłożeniu na skali.

B. Lewandowska-Tomaszczyk (tamże: 28) opowiada się za powrotem do analizy ekwiwalencji, która powinna opierać się na analizie ,,przekładu jako rekonceptualizacji w procesie emergencji znaczeń dyskursywnych” ,poprzez coraz lepsze rozumienie języka i natury komunikowania się."

Jednakże rozpatrywanie ekwiwalencji na tle i w ramach dyskursu jako komunikacji bez uwzględnienia czynnika strategicznego i zakotwiczenia antropocentrycznego nie pozwala na jednoznaczne przezwyciężenie aporyczności relacji wierność vs. wolność budującej określony stopień i rodzaj ekwiwalencji, o którym zawsze decyduje tłumacz w ramach zadaniowego profilu strategii translacyjnej. Próbą idącą w tym kierunku może być propozycja rozwiązania tego klasycznego dylematu trans- 
latorycznego z pozycji holizmu funkcjonalnego usytuowanego w podstawowym paradygmacie translatoryki antropocentrycznej (J. Żmudzki 2013: 177; 2014), który pozwala na swego rodzaju kompromis interpretacyjny wyżej wymienionych koncepcji. Antropocentryczne umiejscowienie rozpatrywanych relacji wierności i wolności oraz bazującej na nich relacji ekwiwalencji opiera się na fundamentalnej tezie, iż centrum procesów translacyjnych zawsze stanowi tłumacz-człowiek wraz z jego realnymi umiejętnościami, zdolnościami, wiedzą i kompetencjami. Ilustracją tych uwarunkowań i odniesień jest model układu translacyjnego, znanego w wersji F. Gruczy $(1986,1990,1993 a, 1993 b, 2008)$ i S. Gruczy $(2010,2011,2014)$ a poszerzonego o moją koncepcję w następującej wersji:

Utr: $\{\operatorname{Itr}, \operatorname{PrTw}, \mathrm{Tw}, \quad \mathrm{Tr}, \mathrm{Td}, \quad \mathrm{Adr}\}$

Itr - inicjator translacji,

PrTw - producent/autor tekstu wyjściowego,

Tw - tekst(/y) wyjściowy(/e),

$\mathrm{T} \nmid$ - tłumacz,

Td - tekst docelowy

Ad - adresat docelowy

Wprowadzenie do tego układu kategorii zadania translacyjnego pozwala na jego istotne zdynamizowanie zgodnie z powszechnie przyjętą interpretacją translacji jako komunikacji, czego bezpośrednią konsekwencją jest i być musi strategiczne profilowanie translacji przez tłumacza w rzeczywistości jej realizacji oraz w jej modelowym przedstawieniu.

Strategiczny profil zadania translacyjnego obejmuje:

1) zdefiniowanie fundamentalnych celów translacji jako celów komunikacji z adresatem docelowym;

2) określenie pożądanego i zamierzonego efektu komunikacyjnego jako projektowanych postaw mentalnych adresata i jego aktywności;

3) uzyskanie pożądanej i możliwie pełnej deskrypcji adresata docelowego;

4) ustalenie trybu/-ów transferowania jako strategicznego/-cznych sposobu/-ów przetwarzania tekstu wyjściowego na docelowy w zakresie jego symulacji i/lub deskrypcji i/lub syntezy i/lub eksplikacji w translacie;

5) recepcyjna rekonceptualizacja oraz zdiagnozowanie/identyfikowanie profilu tekstu wyjściowego pod względem jego funkcji komunikacyjnej (w ramach kom. pierwotnej) oraz jej dystrybucji w tekście, realizacji zamierzonego efektu komunik. u adresata pierwotnego, tematycznego zakresu i specyfiki, rozwinięcia strukturalnego, przynależności rodzajowej

6) określenie/ustalenie profilu tekstu docelowego jako translatu pod względem jego funkcji komunikacyjnej ( $\mathrm{w}$ ramach komunikacji zapośredniczonej translacyjnie) oraz jej dystrybucji $w$ tekście, adekwatnej realizacji zamierzonego efektu komunikacyjnego u adresata zgodnego z intencją inicjatora, tematycznego zakresu i specyfiki, przynależności rodzajowej;

7) pozyskanie i ewaluacja informacji dotyczących elementów, obiektów, 
czynników oraz aktantów tworzących sytuację;

8) określenie i realizacja kolokucyjności celów aktywnych uczestników (adresata) komunikacji przez tłumacza;

9) realizacja procesu translacji: wykonanie wyprofilowanych zadaniowo stosownych operacji translacyjnych w ramach określonego rodzaju translacji w celu skonstruowania funkcjonalnego translatu.

Dzięki tym zabiegom interpretacyjnym poszerzeniu ulega cała perspektywa translacyjna, w której można wyróżnić nowe istotne obszary odniesień dla rozpatrywanych translacyjnie fundamentalnych kategorii, ich modalnościowych determinantach i w związku z tym relacji ekwiwalencji translacyjnej.

Wielowiekową dyskusję na temat tych dwóch przeciwstawnych kategorii stanowiącą podstawę do rozważań nad zjawiskiem i interpretacją ekwiwalencji translacyjnej charakteryzuje względnie marginalne potraktowanie modalności przypisywanych tym pojęciom. A zatem wierność warunkowana jest występowaniem i identyfikacją określonych możliwości zachowania tej wierności (oczywiście przez tłumacza) względem tekstu wyjściowego czyli innymi słowy prawdy o tekście wyjściowym w tekście docelowym. Natomiast wolność (niewierność) od oryginału warunkowana jest wyłącznie występowaniem i identyfikacją określonych konieczności (oczywiście przez tłumacza) w procesie translacji, co zasadniczo dynamizuje wzajemny stosunek tych kategorii do siebie. Tak więc kategoria tej warunkowokoniecznej wolności implikuje i legitymizuje zasadność różnicowania (dyferencjacji jako specyficznej niewierności) jednak zawsze w ramach funkcjonalnej dynamiki każdego procesu translacji. Mówiąc jeszcze inaczej: kategoria wierności umocowana $\mathrm{w}$ procesie translacji implikuje wytwarzanie przez każdego thumacza podstawowej postawy intencjonalnej dającej się opisać w terminach obligacji względem tekstu wyjściowego. W momencie jej utworzenia uruchamia ona mechanizm ewaluacji konstytuentów tekstu wyjściowego pod względem ich odwzorowania i zachowania/usytuowania w tekście docelowym, aby tę obligację/zobowiązanie translatoryczne spełnić, gdyż jest ona konieczna z istoty translacji jako tworzenia najbardziej silnego związku intertekstualnego między dwoma tekstami. Jak już wspomniałem, powołując się na tę klasyczną maksymę św. Hieronima, zarówno wierność jak też i wolność od oryginału posiadają swe prymarnie naturalne uwarunkowania modalnościowe; zatem realizując obligację translatoryczną w procesie translacji tłumacz po pierwsze wyróżnia ewaluacyjnie obszar możliwości koniecznego odwzorowania prototypowego wzorca tekstu wyjściowego w tekście docelowym od obszaru niemożliwości zachowania tegoż wzorca prototypowego lecz $\mathrm{w}$ ścisłym powiązaniu $\mathrm{z}$ innym rodzajem modalności tzn. z koniecznością i tylko z koniecznością zasadnego różnicowania tekstu wyjściowego w ramach tekstu docelowego. A każda możliwość daje się zdefiniować poprzez i na tle wyróżnionej niemożliwości, innymi słowy istnienie możliwości implikuje istnienie niemożliwości tak, jak analogicznie istnienie wierności implikuje niewierność jako specyficzną wolność. I w takim to właśnie sensie odgraniczanie zakresu możliwej wierności odwzorowania prototypowego tekstu wyjściowego implikuje jednoczesne zakreślanie granic wolności względem tekstu wyjściowego. Jednakże modalności dotyczące kategorii wierności i ją deter- 
minujące, jak to wyżej zaznaczyłem, występują w dwóch odmianach: podstawową/fundamentalną modalnością jest konieczność zachowania (przez thumacza) wierności względem tekstu wyjściowego a w związku z tym jego względne prototypowe (bo nie identyczne!) zachowanie i sygnalizowanie zewnętrzną formą tekstu docelowego oraz odtworzenie w ramach tekstu docelowego przez adresata translacji; ponieważ niemożliwe jest utworzenie produktu identycznego, to dopiero na tę podstawową modalność koniecznej wierności nakłada się modalność możliwej wierności determinowanej określonym profilem i zakresem jego komunikacyjnej funkcjonalności w obszarze docelowym. W związku z tym tekst docelowy nie jest i nie może być zupełnie samodzielnym bytem autoreferencyjnym, ponieważ jest zależny od tekstu wyjściowego, pozostaje z nim w ciągłej relacji typu prototyp - derywat a zarazem posiada swą odrębność funkcjonalną, ponieważ w wyniku rekontekstualizacji funkcjonuje $\mathrm{w}$ innej perspektywie komunikacyjnej, w innym lub podobnym celu lecz zawsze dla odmiennego adresata. Konieczność wolności od tekstu wyjściowego nie wynika jedynie z odmienności wzgl. różnic między systemami języka, kultury, komunikacji i realiów tematyzowanych $w$ tekstach $w$ ramach translacji. Istotną determinację wspomnianej konieczności stanowi konstruowany przez tłumacza określony profil zadania translatorycznego $\mathrm{w}$ ramach konkretnego i realnie jednostkowego układu translacyjnego. W związku z tym zarówno konieczność i możliwość wierności względem tekstu wyjściowego, jak też i warunkowa konieczność wolności tekstu docelowego od wyjściowego wynikają z określonych postaw intencjonalno-ewaluacyjnych thumacza. Pierwszy typ tej postawy mentalnej oznacza, że możliwość zachowania wierności wyprowadzana jest z zidentyfikowanych konwergencji i podobieństw między systemami języka, kultury, komunikacji i realiów tematyzowanych i aktualizowanych w tekście wyjściowym odnoszonym w wyniku jego rekonceptualizacji przez thumacza do wymienionych systemów docelowych. Drugi typ postawy intencjonalno-ewaluacyjnych thumacza dotyczy warunkowej konieczności wolności tekstu docelowego od wyjściowego i wynika po pierwsze z zidentyfikowanych dywergencji i różnic między systemami języka, kultury, komunikacji i realiów tematyzowanych i aktualizowanych $\mathrm{w}$ tekście wyjściowym odnoszonym w wyniku jego rekonceptualizacji przez tłumacza do wymienionych systemów docelowych. Po drugie postawa tej warunkowo koniecznej wolności wynika z alteryczności/inności specyfiki zadania komunikacyjnego bazującego na tekście docelowym w porównaniu z zadaniem komunikacyjnym realizowanym przez tekst wyjściowy. Jest to zgodne z zasadą, iż mimetyczność rodzi alteryczność. Jako trzeci czynnik modalnościowy należy uznać alteryczność sytuacji komunikacyjnych, które albo są realizowane $\mathrm{w}$ oparciu o tekst wyjściowy albo o tekst docelowy, gdzie jednym $\mathrm{z}$ czynników różnicujących jest w każdym przypadku odmienny adresat. Bowiem jeną z cech istotnych translacji wg R. Lewickiego $(1993,2000)$ jest zmiana adresata czyli operacja koniecznego przeadresowania $\mathrm{w}$ wyniku rekontekstualizacji zgodnie $\mathrm{z}$ koncepcją B. Lewandowskiej-Tomaszczyk (2010). W związku z tym tekst docelowy to:

a) derywat konceptualno-funkcjonalny (jako kontynuacja tekstu wyjściowego, budująca relację ekwiwalencji i stanowiąca jego powtórną instrumentalizację koaktywacyjną poprzez adekwatność zadaniową - adekwatność wzglę- 
dem celu translacji jako komunikacji);

b) efekt adaptacji kolokucyjnej (adresat docelowy)

c) efekt zastosowania komunikacyjnie adekwatnego trybu transferowania tekstu wyjściowego tzn. jego stosownego przetwarzania względem funkcji docelowej;

d) narzędzie komunikacji sekundarnej (wtórnej);

e) nie-substytut językowy/ nie kopia językowa tekstu wyjściowego w języku docelowym!

Reasumując: Opisane powyżej cechy translatu wykazują specyficzny związek pomiędzy ekwiwalencją, która opiera się na derywacyjnej kontynuacji tekstu wyjściowego w translacie a adekwatnością zadaniową. To właśnie poprzez adekwatność zadaniową translat uzyskuje swą konieczną funkcjonalność komunikacyjną a tekst wyjściowy tym samym powtórną instrumentalizację pomimo koniecznego zabiegu rekontekstualizacji i dyferencjacji. Zatem realizacja fundamentalnej konieczności zachowania wierności jest zawsze zależna od systemowo specyficznych konwergencji i dywergencji, istniejących pomiędzy systemami aktualizowanymi w procesie translacji; i tak też konwergencje wyznaczają zakres systemowych implikacji możliwych ciągłości tekstu wyjściowego lub też ciągłości tożsamościowopodobnościowych w translacie, natomiast dywergencje implikują zakres zasadnych dyferencjacji systemowych w ramach tekstu docelowego. Z drugiej zaś strony konieczność wolności od tekstu wyjściowego jako epistemiczny rodzaj modalności translacyjnej determinowana jest czynnikiem strategicznym translatora. Wyznacza on bowiem zakres i rodzaj zróżnicowania tekstu wyjściowego, niezbędnego dla realizacji komunikacji z adresatem docelowym i wymaganym przez nią. Ten rodzaj modalności posiada status autonomicznej konieczności, ponieważ wynika z rekontekstualizacji i różnicowania funkcjonalnego tekstu wyjściowego w ramach zadania translacyjnego. $Z$ tego względu różnicowanie funkcjonalne można uznać za specyficzną komplementarność funkcjonalną zależną od translacyjnie realizowanej sytuacji docelowej jako komunikacyjnej. Tę autonomiczną konieczność określają takie czynniki alteryczności jak:

a) cel translacji jako komunikacji,

b) zamierzony efekt komunikacyjny u adresata,

c) genologiczny i funkcjonalny profil tekstu docelowego,

d) uwarunkowania pragmatyczne sytuacji translacyjnej jako komunikacyjnej,

e) profil adresata docelowego jako partnera komunikacji,

f) tryby transferowania tekstu wyjściowego.

\section{Bibliografia}

Cruse, D. (1992): Levels of Translation. A Linguistic Perspective. (w:) B. Lewandowska-Tomaszczyk/ M. Thelen (red.), Translation and Meaning, cz. 2. Maastricht, 19-34.

Grucza, F. (1986): Ttumaczenie, teoria ttumaczen, translatoryka.(w:) F. Grucza (red.), Problemy translatoryki i dydaktyki translatorycznej. Warszwa, 9-27. 
Grucza, F. (1990): Zum Forschungsgegenstand und -ziel der Übersetzungswissenschaft.(w:) R. Arntz/ G. Thome (red.), Übersetzungswissenschaft: Ergebnisse und Perspektiven. Tübingen, 9-18.

Grucza, F. (1993a): Interkulturelle Translationskompetenz: ihre Struktur und Natur. (w:) A. P. Frank/ K.-J. Maaß, /F., Paul, /H. Turk, (red.), Übersetzen, verstehen, Brücken bauen. Geisteswissenschaftliches und literarisches Übersetzen im internationalen Kulturaustausch. Berlin.

Grucza, F. (1993b): Język, ludzkie właściwości językowe, językowa zdolność ludzi. (w:) J. Piontek, J./A. Wiercińska (red.), Człowiek w perspektywie ujęć biokulturowych. Poznań, 151-174.

Grucza, F. (2008): Germanistische Translatorik - ihr Gegenstand und ihre Aufgaben. (w:) F. Grucza (red.), Translatorik in Forschung und Lehre der Germanistik. Warszawa, 27-53.

Grucza, S. (2010): Gtówne tezy antropocentrycznej teorii języków. (w:) Lingwistyka Stosowana/ Applied Linguistics/ Angewandte Linguistik, 2, 41-68.

Grucza, S. (2011): Lingwistyka antropocentryczna a badania okulograficzne. (w:) Lingwistyka Stosowana/ Applied Linguistics/ Angewandte Linguistik, 4, 149163.

Grucza, S. (2014): Grundzüge der anthropozentrischen Translatorik. (w:) A. ŁypBielecka (red.) Mehr als Worte. Sprachwissenschaftliche Studien. Katowice.

Gutt, E.A. (1991): Translation and Relevance. Cognition and Context. Oxford/ Cambridge.

Gutt, E.A. (1997): Relevance: a key to quality assessement in translation. (w:) B. Lewandowska-Tomaszczyk, M. Thelen (red.), Translation and Meaning, cz. 4. Maastricht.

Heidegger, M. (2010): Identyczność i różnica. Tłum. J. Mizera. Warszawa

Hieronymus (1973): Ad Pammachium de optimo genere interpretandi. Epist. 57. (w:) H.-J. Störig (red.) Das Problem des Übersetzens. Darmstadt, 1-13.

Holz-Mänttäri, J. (1984): Translatorisches Handeln. Theorie und Methode. Helsinki. Holz-Mänttäri, J. (1986): Translatorisches Handeln - theoretisch fundierte Berufsprofile. (w: ) M. Snell-Hornby, (red.), Übersetzungswissenschaft - eine Neuorientierung. Tübingen, 348-374.

Hönig, H./ Kussmaul, P. (1982): Strategie der Übersetzung. Tübingen.

Ingarden, R. (2000): Szkice z filzofii literatury. Kraków.

Kade, O. (1968) Zufall uund gesetzmäßigkeit in der Übersetzung. Leipzig.

Kasperski, E. (1992): Aspekty mimesis.(w: ) Z. Mitosek (red.), Mimesis w literaturze, kulturze i sztuce. Warszawa, 65-93.

Kenny, D. (1998): 'Equivalence', in the Routledge Encyclopaedia of Translation Studies, edited by Mona Baker. London/ New York 77-80.

Kielar, B.Z. (1988): Ttumaczenie i koncepcje translatoryczne. Wrocław/ Warszawa. Kielar, B.Z. (2003): Zarys translatoryki. Warszawa.

Koller, W. (1992 I 2004): Einführung in die Übersetzungswissenschaft. Wiesbaden/ Heidelberg.

Kussmaul. P. (1986): Übersetzen als Entscheidungsprozess. Die Rolle der Fehler- 
analyse in der Übersetzungsdidaktik. (w:) M. Snell-Hornby (red.), Übersetzungswissenschaft - eine Neuorientieerung. Tübingen, 206-229.

Kussmaul, P. (2000): Kreatives Übersetzen. Tübingen.

Ladmiral, J.-R. (1981): La traduction comme linguistique d'intervention.(w:) W. Pöckl, (red.): Europäische Mehrsprachigkeit. Festschrift zum 70. Geburtstag von Mario Wandruschka. Tübingen, 375-400.

Lewandowska-Tomaszczyk B. (2010): Nowe spojrzenie na przekład: podobieństwo, granice ekwiwalencji i rekonceptualizacji. (w:) Lingwistyka Stosowana/ Applied Linguistics/ Angewandte Linguistik, 3, 9-31.

Lewicki, R. (1993): Konotacja obcości w przekładzie. Lublin.

Lewicki, R. (2000): Obcość w odbiorze przekładu. Lublin.

Luther, M. (1973): Ein Sendbrieff D.M. Luthers. Von Dolmetzschen vund Fürbitt der Heiligen (Nürnberg 1530). (w:) H.-J. Störig, (red.), Das Problem des Übersetzens. Darmstadt, 14-32.

Minjar-Bełoruczew, R.K. (1980): Obszczaja tieorija pieriewoda i ustnyj pieriewod. Moskwa.

Nord, CH. (1988 i 1991): Textanalyse und Übersetzen. Heidelberg.

Nord, CH. (1989): Loyalität statt Treue. Vorschläge zu einer funktionalen Übersetzungstypologie. Lebende Sprachen, 34, 100-105.

Nycz, R. (1993): Tekstowy świat: poststrukturalizm a wiedza o literaturze. Warszawa.

Pym, A. (1992): Translation and Text Transfer. An Essay of Pronciples of Intercultural Communications. Frankfurt/ M.

Ress, K./ H.J. Vermeer (1984): Grundlegung einer allgemeinen Translationstheorie. Tübingen.

Schleiermacher, F. (1838): Über die verschiedenen Methoden des Übersetzens. (w:) Friedrich Schleiermachers sämtliche Werke, Dritte Abtheilung: Zur Philosophie. Bd. II. Berlin, 207-245.

Siever, H. (2010): Übersetzen und Interpretation. Die Herausbildung der Übersetzungswissenschaft als eigenständige wissenschaftliche Disziplin im deutschen Sprachraum von 1960 bis 2000. Frankfurt/ M.

Snell-Hornby, M.(red.) (1986): Übersetzungswissenschaft. Eine Neuorientierung. Tübingen.

Snell-Hornby, M. (1988): Translation Studies. An Integrated Approach. Amsterdam. Stolze, R. (2003): Hermeneutik und Translation. Tübingen.

Szwejcer, A.D. (1988): Tieorija pieriewoda. Status, problemy, aspekty. Moskwa.

Tabakowska, E. (2001): Językoznawstwo kognitywne a poetyka przekładu. Kraków.

Urbanek, D. (2004): Pęknięte Lustro. Tendencje w teorii i praktyce przekładu na tle myśli humanistycznej. Warszawa.

Venuti, L (1995): The Translator's Invisibility. A History of Translations. London/ New York.

Wilss, W. (1988): Kognition und Übersetzen. Zur Theorie und Praxis des menschlichen und maschinellen Übersetzung. Tübingen.

Ziomek, J. (1975): Kto mówi?, (w:) Teksty, 6, 44-55. 
Żmudzki, J. (1991): Zum Problem der bilingualen Äquivalenz lexikalischer Einheiten. UMCS Lublin.

Żmudzki, J. (2013): Holizm funkcjonalny w perspektywie translatoryki antropocentrycznej. (w:) Lingwistyka Stosowana/ Applied Linguistics/ Angewandte Linguistik, 8, 177-188.

Żmudzki, J. (2014): ,so treu, wie möglich, so frei, wie nötig “ - eine alte Translationsmaxime neu interpretiert. (w:) A. Łyp-Bielecka, (red.), Mehr als Worte. Sprachwissenschaftliche Studien. Katowice, 345-360.

Żmudzki, J. (2015): Blattdolmetschen in paradigmatischer Perspektive der anthropozentrischen Translatorik. Frankfurt/ M. 